\title{
中国植被分类系统修订方案
}

\author{
郭 柯 ${ }^{1,2}$ 方精云 ${ }^{1,3}$ 王国宏 ${ }^{1}$ 唐志尧 ${ }^{3}$ 谢宗强 ${ }^{1,2}$ 沈泽昊 ${ }^{3}$ 王仁卿 ${ }^{4}$ 强 胜 $^{5}$ \\ 梁存柱 $^{6} \quad$ 达良俊 $^{7}$ 于 丹 $^{8}$
}

${ }^{1}$ 中国科学院植物研究所植被与环境变化国家重点实验室, 北京 $100093 ;{ }^{2}$ 中国科学院大学资源与环境学院, 北京 $100049 ;{ }^{3}$ 北京大学城市与环境学院, 北京大学生态研究中心, 北京 $100871 ;{ }^{4}$ 山东大学生命科学学院, 济南 $250100 ;{ }^{5}$ 南京农业大学生命科学学院, 南京 $210095 ;^{6}$ 内蒙古大学生态与环境学 院, 呼和浩特 $0100217^{7}$ 华东师范大学生态与环境科学学院, 上海 $200241{ }^{8}$ 武汉大学生命科学学院, 武汉 430072

摘 要 为了推动 《中国植被志》研编工作, 该文回顾了中国植被分类系统的发展过程和主要阶段性成果, 提出了作为《中 国植被志》研编技术框架组成部分的中国植被分类系统修订方案, 对各植被型组及各植被型进行了简单定义和描述, 并针对 中国植被分类系统若干问题，特别就中国植被分类系统总体框架、混交林的界定以及土壤在植被分类中的重要性等问题进行 了讨论。1960年侯学显在《中国的植被》中首次提出了中国植被分类的原则和系统，1980年出版的《中国植被》制定了分类 等级和划分依据等更加完善的系统, 之后《中国植被及其地理格局一一华人民共和国1:1000 000植被图说明书》和《中国 植物区系与植被地理》以及很多省区的植被专著对该系统进行过修订。2017年宋永昌在《植被生态学》中提出了一个分类等 级单位调整的方案。本次提出的中国植被分类系统修订方案基本沿用《中国植被》的植被分类原则、分类单位及系统, 采 用“植物群落学-生态学”分类原则, 主要以植物群落特征及其与环境的关系作为分类依据, 包含三级主要分类单位, 即植被 型(高级单位)、群系(中级单位)和群从(低级单位); 在三个主要分类单位之上分别增加辅助单位植被型组、群系组和群从组, 在 植被型和群系之下主要根据群落的生态差异和实际需要可再增加植被亚型或亚群系。修订方案包含了森林、灌从、草本植被 (草地)、荒漠、高山冻原与稀疏植被、沼泽与水生植被(湿地)、农业植被、城市植被和无植被地段 9 个植被型组, 划分为 48 个 植被型(含30个自然植被型、12个农业植被型、5 个城市植被型和无植被地段)。自然植被中有 23 个植被型进一步划分出了 81 个植被亚型。

关键词 植被分类; 植被型; 群系; 群丛; 群落外貌; 群落生态特征; “植物群落学-生态学”分类原则

郭柯, 方精云, 王国宏, 唐志尧, 谢宗强, 沈泽吴, 王仁卿, 强胜, 梁存柱, 达良俊, 于丹 (2020). 中国植被分类系统修订方案. 植物生态学报, 44, 111-127. DOI: $10.17521 /$ cjpe.2019.0271

\section{A revised scheme of vegetation classification system of China}

GUO Ke ${ }^{1,2^{*}}$, FANG Jing-Yun ${ }^{1,3}$, WANG Guo-Hong ${ }^{1}$, TANG Zhi-Yao ${ }^{3}$, XIE Zong-Qiang ${ }^{1,2}$, SHEN Ze-Hao ${ }^{3}$, WANG Ren-Qing ${ }^{4}$, QIANG Sheng ${ }^{5}$, LIANG Cun-Zhu ${ }^{6}$, DA Liang-Jun ${ }^{7}$, and YU Dan ${ }^{8}$

${ }^{1}$ State Key Laboratory of Vegetation and Environmental Change, Institute of Botany, Chinese Academy of Sciences, Beijing 100093, China; ${ }^{2}$ College of Resources and Environment, University of Chinese Academy of Sciences, Beijing 100049, China; ${ }^{3}$ Institute of Ecology, College of Urban and Environmental Sciences, Peking University, Beijing 100871, China; ${ }^{4}$ School of Life Sciences, Shandong University, Jinan 250100, China; ${ }^{5}$ School of Life Sciences, Nanjing Agricultural University, Nanjing 210095, China; ${ }^{6}$ School of Ecology and Environment, Inner Mongolia University, Hohhot 010021, China; ${ }^{7}$ School of Ecological and Environmental Sciences, East China Normal University, Shanghai 200241, China; and ${ }^{8}$ College of Life Sciences, Wuhan University, Wuhan 430072, China

Abstract

The principles and scheme of vegetation classification system of China (China-VCS) were first proposed by Hou in China's Vegetation in 1960. An improved hierarchy framework and criteria of China-VCS were published in Vegetation of China in 1980. China-VCS was revised in Vegetation of China and Its Geographic Pattern - Illustration of the Vegetation Map of the People's Republic of China (1:1000 000) in 2007 and in Flora and Vegetation Geography of China in 2014. Song proposed a new scheme in the text book Vegetation Ecology in 2017. To facilitate Chinese vegetation study and the compilation of the book series on the vegetation of China (Vegegraphy of China), this paper provides a revised scheme of China-VCS. The scheme adopts the principles, units and hierarchy structure in the Vegetation of China that was considered as a milestone in the development of Chinese vegetation science. Based on the phytocoenological-ecological principles, plant community features and its ecological

收稿日期Received: 2019-10-15 接受日期Accepted: 2019-12-16

基金项目: 国家科技基础性工作专项(2015FY210200)、国家科技基础资源调查专项(2019FY202300)和中国科学院战略性先导科技专项 (XDA19050402)。Supported by the Special Foundation for National Science and Technology Basic Research Program of China (2015FY210200), the Special Foundation for National Science and Technology Basic Resources Investigation of China (2019FY202300), and the "Strategic Priority Research Program" of the Chinese Academy of Sciences (XDA19050402).

* E-mail: guoke@ibcas.ac.cn 
conditions are considered as the key criteria for vegetation classification. There are three levels including eight units in the hierarchy framework of China-VCS: upper level (Vegetation Formation Group, Vegetation Formation, and Vegetation Subformation), middle level (Alliance Group, Alliance, Suballiance), and lower level (Association Group, Association). Nine Vegetation Formation Groups are defined as Forest, Shrubland, Herbaceous Vegetation (Grassland), Desert, Alpine Tundra and Sparse Vegetation, Swamp and Aquatic Vegetation (Wetlands), Agricultural Vegetation, Urban Vegetation, and Non-vegetated Area. Forty-eight Vegetation Formations (30 for natural and semi-natural vegetation, 12 for agricultural vegetation, 5 for urban vegetation, and one for Non-vegetated Area) are defined, including 81 Vegetation Subformations from 23 natural and semi-natural vegetation formations. These vegetation formation groups and 30 natural and semi-natural vegetation formations were described briefly. Some issues on China-VCS, especially on the framework, criterion identifying mixed-forest, and the role of soil in vegetation classification, are discussed.

Key words vegetation classification; Vegetation Formation; Alliance; Association; community physiognomy; community ecological feature; the phytocoenological-ecological principles

Guo K, Fang JY, Wang GH, Tang ZY, Xie ZQ, Shen ZH, Wang RQ, Qiang S, Liang CZ, Da LJ, Yu D (2020). A revised scheme of vegetation classification system of China. Chinese Journal of Plant Ecology, 44, 111-127. DOI: 10.17521/cjpe.2019.0271

植被是某一地段内所有植物群落的集合(方精 云等, 2020)。植被分类是根据植物群落特征及其与 环境的关系, 按照一定的划分原则和等级系统进行 逐级组合归类。植被分类的目的在于依据统一的分 类标准, 准确地描绘植物群落的种类组成、外貌、 结构、动态及其生境的特征, 反映群落类型多样性 及不同类型之间的差异, 增进对植物群落及其与环 境之间相互关系的认识，探讨不同地区植被的联系; 同时, 通过整理植被资源的本底资料, 为数据共享 和学术交流建立统一标准, 为合理利用和保护自然 资源提供科学依据(中国植被编辑委员会, 1980; 侯 学显, 1994; 陈灵芝等, 2014; 宋永昌, 2017)。

由于全球植被的复杂多样性, 不同地区植被类 型及其复杂程度存在差别, 植被分类研究形成了多 个具有区域特色的学术传统, 如法瑞学派、北欧学 派、英美学派、苏联学派等, 在植物群落的概念内 涵、分类依据和标准等方面都存在较明显的差异。 至今, 全世界尚未形成一个统一的植被分类体系。 从 20 世纪70年代以来, 国际植被学界通过一系列国 际合作项目，持续致力于各植被分类系统之间的资 料对照和系统衔接与整合(UNESCO, 1973; Dengler et al., 2013; Faber-Langendoen, 2014; De Cáceres et al., 2015; 宋永昌, 2017)。2018年, 国际植被调查和分类 学期刊《Phytocoenologia》发表了一个植被分类系 统和方法的专辑(第48卷 2 期), 集中刊载了13篇论文, 介绍国际上主要的植被分类系统和方法(Brown \& Bredenkamp, 2018; Chytrý \& Tichý, 2018; FaberLangendoen et al., 2018; Gellie et al., 2018; Gillet \& Julve, 2018; Guarino et al., 2018; Guo et al., 2018;
MacKenzie \& Meidinger, 2018; Peet et al., 2018; Rodwell, 2018; Walker et al., 2018; Wiser \& De Cáceres, 2018), 并对这些植被分类系统进行了比较 (De Cáceres et al., 2018)。

\section{1 中国植被分类系统的形成和修订}

中国是世界上植被类型最丰富的国家之一, 但 植被生态学研究起步较晚。1949年新中国成立以前, 全国仅有少数高校和研究机构的少数研究人员在局 部区域开展了零星植被调查, 研究成果主要是调查 成果的报道, 缺乏系统性的植被分类研究。新中国 成立后, 中央政府在恢复发展农业生产和实施国土 资源开发与整治等一系列国民经济重大任务过程中, 急需了解植被资源的基本情况和开发潜力。由此, 大规模植被调查才有目的有计划地开展起来(侯学 显, 1960; 中国植被编辑委员会, 1980; Qian, 2004; Guo et al., 2018)。

\section{1 新中国成立初期的植被研究}

20 世纪 50 年代, 全国植被调查和植被分类与区 划等地植物学研究受苏联科技援华专家的指导, 研 究方法和成果总结都具有明显的苏联学派的特点。 全国性植被分类和区划的代表性成果主要有两个。 一是1956年钱崇澍等在《地理学报》发表了《中国 植被的类型》一文。该文结合中国植被区划将全国 植被划分了12个类型, 作为各植被地带的代表性植 被类型, 相当于生物地理群落类型或生物群区的概 念(钱崇澍等, 1956)。二是1957年，陈昌笃在吴征镒 先生指导下编绘的 $1: 1800$ 万《中国植被简图》中进 一步划分出 18 个植被类型(见1957年10月内部发行 
的《中华人民共和国地图集》)。二者均未涉及植被 类型划分的原则和等级系统。

1958年, 中国科学院植物研究所邀请苏联科学 院通讯院士E. M. 拉甫连科来华讲学, 之后出版了 《植物群落的基本规律及其研究的途径》(拉甫连科, 1959), 对中国植被科学和植被分类研究具有重要 的指导作用, 其中有关植被分类的主要单位和结构 在随后的中国植被分类系统中得到沿用。

1960年，人民教育出版社出版了侯学显的《中 国的植被》一书。该书对中国植被的总体概貌进行 了系统分析，并首次提出了中国植被分类的“植物 群落学-生态学” 原则和分类系统草案, 确定了植被 型、群系、群丛三级为中国植被分类的主要单位, 并 在群系和群从之上分别加入群系组和群从组两个辅 助级。该书所附的 $1: 800$ 万中国植被图, 包含 137 个 图例, 是当时最详细的中国植被图。另外, 该书还指 出群系组与植被型之间可能需要再增加一级。该书 提到了栽培植被, 但仅对暖温带落叶阔叶林区域和 亚热带常绿阔叶林区域的栽培植被进行了概括性的 描述。

\section{2 《中国植被》编写出版}

1976年开始, 中国科学院组织全国地植物学研究 力量开展了《中国植被》的研编工作。侯学显(1960) 提出的全国植被分类原则和等级框架被采用, 并在 等级系统、划分依据等方面进行了完善: (1)在植被 型级之上增加辅助级植被型组, 在植被型级之下增 加辅助级植被亚型, 在群系级之下增加辅助级亚群 系; (2)完善各级分类单元植被特征及其与生态地理 特征的联系和具体划分依据; (3)为配合植被分类依 据的制定，编制了对应的植物生活型系统表和植物 生态类型表; (4)单独编制栽培植被及其分类原则和 系统(中国植被编辑委员会, 1980)。《中国植被》所 确定的植被分类原则、依据和等级系统被人们习惯 地称为“80方案”, 这一方案在后来出版的绝大部分 省级和区域植被专著、植被考察报告中得到了广泛 应用, 部分专著还根据所研究地区的自然环境和植 被特点进行了局部的修编(黄威廉等, 1988; 中国科 学院青藏高原综合科学考察队, 1988)。

然而，限于当时植被资料相对贵乏，编写时间 紧迫, 参与人员众多, 撰写人员背景不同, 以及对 部分植被类型的认识存在差异等多种因素, “80方 案” 中部分内容的处理方式存在瑕疵或相互矛盾之
处, 或未能完全取得共识(王伯䔉, 1987; 朱华, 2005; 宋永昌, 2011; 陈灵芝等, 2014; 宋永昌等, 2017)。其 中存在争议的问题主要包括:

(1)描述的分类依据与实际划分结果有脱节现 象，如植被型划分依据是一级或二级生活型，但在 实际划分时没有严格地应用; (2)将温性针阔叶混交 林划归针叶林之下; (3)在森林的分类中, 特别强调 优势物种针叶与阔叶生活型的区别, 却未能同等重 视落叶与常绿习性决定的群落季相特征和生态过程 的巨大差异; (4)将中生草本植物为建群种的次生性 (灌)草丛与灌从列在同一个植被型组, 而不是与其 他中生草本植物为优势的植被类型在一起; (5)将中 生草本植物为建群种的次生性稀树草原(稀树草丛) 与旱生植物为主的草原置于同一个植被型组, 而不 是与中生草本植物为优势种的草甸置于相同的植被 型组; (6)生活型系统中未列入常绿革叶灌木和硬叶 常绿阔叶乔木, 但为强调分布生境的特殊性, 划分 出常绿革叶灌从植被型和硬叶常绿润叶林植被型, 与其他植被型划分相比, 划分依据比较含糊, 事实 上, 许多常绿阔叶灌从建群种叶片也是革质的; (7) 相应地，对荒漠、草原、草甸等植被型组中生活型 明显不同、群落外貌同样存在较大差异的植被类型 都没有给予同等的区分; 小半乔木荒漠、灌木荒漠、 半灌木与草本荒漠等没有在植被型一级按照建群层 片的生活型进行划分; (8)依据优势种或标志种两个 不同指标划分出的群系和群丛不等质(宋永昌, 2011); (9)植被类型命名方法不统一。

上述问题在此后的植被分类系统方案中得到过 部分修订和完善(中国科学院中国植被图编辑委员 会, 2007a, 2007b; 陈灵芝等, 2014; 宋永昌, 2017)。

\section{3 中国植被图的编制}

1:100万中国植被图的编制是在上述研究积累 的基础上展开的。1980年11月提出了《中国植被图、 植被区划图编制规范(草案)》和《中国植被分类系 统(草案)》，1988年3月进一步讨论和修改了图例系 统(中国科学院中国植被图编辑委员会, 2007b)。 2001 和 2007 年, 《中国植被图集》(中国科学院中国 植被图编辑委员会, 2001)、《中华人民共和国植被 图》和《中国植被及其地理格局一一中华人民共和 国植被图(1:1000 000)说明书》(中国科学院中国植 被图编辑委员会, 2007a, 2007b)先后出版, 反映了 同一时期中国植被研究的整体成果。其中, 植被分 
类原则、依据和等级与《中国植被》基本一致, 但 没有列出具体的分类系统。图例系统显示，与“80方 案”相比有很多的调整, 主要有: (1)在植被型组级, 将针润混交林、灌草从分别从针叶林、灌从和灌草 从中独立了出来, 并新建立了两个植被型组; 将冻 原、高山稀疏植被合并新建了高山植被植被型组; 新建沼泽植被植被型组替代了原沼泽与水生植物群 落植被型组; 没有涉及水生植物群落, 这可能与水 生植物群落难以在这样的小比例尺植被图上表现有 关。(2)在植被型级和亚型级, 共设置了 55 个分类单 元, 植被亚型的等级单位说明中提到新设置了 2 个 亚型, 分别为亚热带和热带山地针叶林、温带落叶 小叶疏林, 但未说明它们所属的植被型和与之并列 的其他植被亚型。(3)图例说明提到, 第三级单位包 括了 11 个群系组、 571 个群系、 4 个亚群系, 第四级 包括了29个群系、244个亚群系。

\section{4 《中国植物区系与植被地理》出版}

《中国植被》(中国植被编辑委员会, 1980)和

《广东植被》(广东省植物研究所, 1976) 出版之后, 全国大部分省级植被专著陆续出版, 中国植被调查 和植被分类研究得到了全面深化。2014年, 《中国 植物区系与植被地理》出版, 该专著参考了 2006 年 以前出版的绝大部分国内植被专著、植被图图例和 多方专家意见，同时考虑到“80方案”已被国内多数 学者所熟悉和广泛使用的现实, 确定植被分类仍沿 用“80方案”的“植物群落学-生态学”分类原则、植被 分类等级及其分类单元名称, 但对各级分类单位的 划分依据进行了部分修订, 尽量使划分依据与划分 的结果保持相对统一, 并提出了各级植被类型的命 名原则, 同时弃用了部分有较大争议的植被类型名 称。分类系统将中国的自然植被划分为 7 个植被型 组、 40 个植被型, 其中有 29 个植被型包含了共 92 个 亚型, 其余 11 个植被型没有划分亚型。在各植被型 的描述中涉及近千个群系(陈灵芝等, 2014)。

\section{5 《中国植被志》研编过程中的相关讨论}

在《中国植被志》研编初期的研讨过程中, 植 被分类系统再次成为多方专家关注的焦点。2010年7 月10日的《中国植被志》通讯第二期刊载了“啯植 被分类简表”, 展示了全国 40 个植被型、约107个植 被亚型、505个群系组和1 035 个群系, 同时刊载了中 国台湾的《台湾植被志》和《日本植被志》介绍, 以 及就植被分类问题和植被志研编对部分专家的专访
等, 供参与 《中国植被志》研编的专家们讨论。宋 永昌(2011)在《植物生态学报》撰文《对中国植被 分类系统的认知和建议》, 肯定了中国植被分类的 原则, 指出了“80方案”中存在的一些问题和修改建 议。2017年, 他和同事再次在《植物生态学报》撰 文《再议中国的植被分类系统》, 并在2017年出版 的《植被生态学》教科书中提出调整后的中国植被 分类系统。该方案综合考虑了国内植被分类现状与 国际主流植被分类系统的衔接, 对植被分类的等级 系统进行了重新设置, 包括植被纲(Class of vegetation types)、植被亚纲(Subclass of vegetation types)、 植被型组 (Group of vegetation types)、植被型 (Vegetation type)、植被亚型(Vegetation subtype)、集 群(Collective group)、优势度型(Dominant type)、群 从(Association)、基群丛(Sociation)等分类等级单位, 同时强调了植被类型在地理空间和生态上的差异性, 如对亚热带常绿阔叶林和热带雨林、季雨林等植被 类型按照西部、东部、台湾等在植被亚型上进行了 区分。该方案系统性较强, 与国际主流植被分类系统 有较好的对应性, 但分类单元与国内现在通用的存 在较多差异, 如以往方案中的落叶阔叶林、常绿阔 叶林等植被型级分类单元在该方案中被提升到了植 被型组, 针阔混交林、肉刺灌从、竹林与竹丛等提 升到了高于植被型两个级别的植被亚纲。

\section{2 中国植被分类系统的修订方案}

作为《中国植被志》技术框架的一部分, 本次 中国植被分类系统的修订方案在积极吸纳国际植被 研究前沿思想的同时, 充分考虑中国植被分类系统 的历史成果, 在强调分类方法科学性的同时, 注重 分类结果的实用性。因此, 修订方案沿用国内广泛 使用的“植物群落学-生态学”分类原则、等级单位和 划分依据的基本内容。同时, 对过去几个方案中存 在的部分问题进行了修订和补充。依据多次植被志 研编研讨会、植被分类系统修订专题会和专家通讯 的综合意见, 求同存异, 形成了对中国植被分类原 则、等级单位、高级单位划分等问题的处理方案。 另外，对植被分类等级单位中英文对照命名问题进 行了确认和修订。各级分类单位划分所采用的依据 实际上是联系划分结果不断完善的。

\section{1 分类原则}

本方案沿用的“植物群落学-生态学”分类原则 
的基本思想是: 以植物群落本身特征和群落所处的 生态条件作为划分植被类型的依据, 但对不同等级 单位采用的具体特征和指标则有所偏重, 高级单位 偏重于群落的生态和外貌, 中级和低级单位偏重于 群落的种类组成和群落结构, 其中也蕴含着生态条 件(侯学显, 1960; 中国植被编辑委员会, 1980; 中国 科学院中国植被图编辑委员会, 2007b; 陈灵芝等, 2014; 宋永昌, 2017; Guo et al., 2018)。鉴于这些原 则在前述的多个植被分类方案中都有详尽的阐述, 这里仅概括介绍如下:

\subsection{1 植物群落的外貌和结构}

植物群落的外貌通常由群落建群种的生活型来 刻画, 而群落结构中的层片结构和群落分析时的功 能群划分也是根据植物生活型来划分的。建群种生 活型及生态适应性相同或相似的植被类型, 其群落 学特征和生存环境也往往相似。所以, 由植物生活 型决定的植物群落外貌和结构以及群落生境条件是 划分植被类型高级单位的主要依据。此方案仍主要 参考《中国植被》中的生活型系统(中国植被编辑委 员会，1980）。鉴于该生活型系统中没有硬叶常绿阔 叶乔木和常绿革叶灌木, 同时也考虑到其属性特点, 将原来的硬叶常绿阔叶林植被型、常绿革叶灌从植 被型分别归并到常绿阔叶林植被型和常绿阔叶灌从 植被型之中, 但基于他们明显的生态特性而划分出 相应的植被亚型。

\subsection{2 植物群落的生态地理特征和植物的生态特性}

群落建群种生活型相同, 甚至建群种相同的植 物群落由于分布的生态地理因素和植物生态类型的 不同, 其群落特征也常常存在较大的差异。如同为 灌木, 中生灌木形成植株密度高、盖度大、生产力 高的灌从, 而超旱生灌木则形成植株稀疏、盖度低、 生产力低下的荒漠, 两者的群落外貌、种类组成和 结构等完全不同。再如, 湿生草本植物形成沼泽, 中 生和旱生草本植物形成草地(草甸和草原)。又如, 芦 苇(Phragmites australis)为建群种的群落, 在水体中 形成水生植被, 但在湿生生境形成沼泽, 在中生生 境形成草地(草甸)。

\subsection{3 植物群落的种类组成}

种类组成是植物群落的主要特征, 理所当然地 是群落分类的主要依据。具体来说, 高级和中级分 类单位通常考虑群落建群种或共建种, 而低级分类 单位需要考虑所有优势种甚至所有组成种类。对于
生态幅度较广的建群种类型而言，其他优势种、区 别特征种甚至种类组成也可能成为确定群落高级分 类单位的重要依据。如以羊茅(Festuca ovina)为建群 种的群落, 主要根据其种类组成及其反映的生态条 件，划分成“羊茅、杂类草草甸草原”、“羊茅(典型) 草原”、“羊茅+新疆针茅 + 纤细绢蒿荒漠草原”、“羊 茅+野青茅、杂类草草甸”、“羊茅、杂类草高寒草甸” 等分属于不同植被型或植被亚型的类型(中国科学 院中国植被图编辑委员会, 2007b)。

\subsection{4 植物群落的动态特征}

植被分类首先考虑植物群落的现状特征，兼顾 群落动态特征。广布于中国南方山地的草从一般是 森林反复破坏后的次生类型，处在一定的演替阶段， 与同样以中生草本植物为建群种的草地(草甸)有本 质的区别。因此, 将草从(灌草丛)单独划分为一个植 被型。另外, 对处于演替过程中的一些次要的演替 系列类型, 特别是极度不稳定的类型, 往往适当节 略处理, 大部分直接归并到其顶极类型或最接近的 演替稳定阶段。如在内蒙古中西部流动和半流动沙 地和沙漠中, 由沙蓬(Agriophyllum squarrosum)、雾 冰僽(Bassia dasyphylla)和狗尾草(Setaria viridis)等 一年生植物为优势的群落是极不稳定的先锋类型, 受环境变化和人类活动影响而变化极大, 通常仅笼 统地称为沙地一年生植物群落, 将其纳入与之相关 的顶极群落或演替过程中相对稳定的一种植物群落 类型中加以说明。

\section{2 分类等级单位及其依据}

修订方案沿用的三级主要分类单位是植被型 (Vegetation Formation, 早期使用Vegetation type)、 群系 (Alliance, 早期使用 Formation) 和群丛 (Association)。各主要单位之上增加同级的“组”, 即 植被型组(Vegetation Formation Group，早期使用 Vegetation type group)、群系组(Alliance Group, 早 期使用Formation group)、群丛组(Association Group); 在植被型和群系之下根据实际需要可以分别增加一 个辅助单位，即植被亚型(Vegetation Subformation, 早期使用Vegetation subtype)、亚群系(Suballiance, 早期使用Subformation)。有关各单位对应英文词汇 的说明, 参见方精云等(2020)和王国宏等(2020)的 文章。各级单位的划分依据如下:

植被型组。最高级别分类单位。主要依据植被 外貌特征和综合生态条件进行划分, 反映陆地生物 
群区主要植被类型和主要非地带性植被类型。本方 案将中国植被划分为森林、灌丛、草本植被(即草地, 含早期分类方案中的草原、草甸、草丛和稀树草原)、 荒漠、高山冻原与稀疏植被、沼泽与水生植被(即湿 地) 6 个自然和半自然的植被型组(各类型的基本特 征见本文第4部分)。另外, 与人类日常生活密切相 关的农业植被和城市植被分别作为两个植被型组对 待, 这主要是从生态系统大类的对应性考虑, 即农 田生态系统、城市生态系统在单位等级上对应于森 林生态系统、草地生态系统、湿地生态系统等。对 于无高等植物或几乎没有高等植物生长的特殊地段, 如冰川、盐壳等, 在进行植被空间分布刻画的时候, 也作为一个类型组。

植被型。主要高级分类单位。在同一个植被型 组内, 建群种或优势层植物生活型组成相同或相近, 结构相对一致的植物群落联合即为植被型。自然植 被划分为 30 个植被型, 农业植被划分为 12 个植被型, 城市植被划分为 5 个植被型(附录I)。

森林植被型组下划分 11 个植被型: 落叶针叶 林、落叶针叶与常绿针叶混交林、常绿针叶林、针 叶与阔叶混交林(群落中针叶树与阔叶树的重要值 在 $25 \%-75 \%$ 之间划归为针叶与阔叶混交林; 如果群 落中针叶树的重要值不足 $25 \%$, 可认定该群落为阔 叶林; 如果针叶树的重要值超过了 $75 \%$, 则视其为 针叶林)、落叶阔叶林、常绿与落叶阔叶混交林(常 绿阔叶树或落叶阔叶树的重要值在 $25 \%-75 \%$ 之间)、 常绿阔叶林(含常绿硬叶阔叶林)、雨林(主要为季节 性雨林)、季雨林、红树林、竹林。

灌丛植被型组下划分 5 个植被型：常绿针叶灌 从一落叶阔叶灌丛、常绿阔叶灌丛(含常绿革叶灌 丛)、肉质刺灌丛、竹丛。

草本植被植被型组下根据优势植物生活型和群 落结构与成因等特征划分 6 个植被型: 丛生草类草 地、根茎草类草地、杂类草草地、半灌木草地、灌 草丛、稀树草丛。

荒漠植被型组下划分 2 个植被型: 半乔木与灌 木荒漠、半灌木与草本荒漠。

高山冻原与稀疏植被植被型组下划分 3 个植被 型: 高山冻原、高山垫状植被、高山稀疏植被。

沼泽与水生植被植被型组下根据优势植物生活 型和生态类型及群落结构等特征划分 3 个植被型: 木本沼泽、草本与苔藓沼泽、水生植被。
农业植被根据农业生产目的和产品用途划分出 了粮食作物、油料作物、纤维作物、糖料作物、药 用作物、饮料作物、饲料作物、烟草作物、菜园、 果园、花卉园、其他经济作物等类型(可以视同植被 型)。

城市植被根据植被的优势植物生活型、群落布 局结构和功能等划分出了城市森林、城市草地、城 市湿地、城市行道树、城市公园植被等。

无植被地段主要包括: 冰川、多年积雪、盐壳、 裸山、熔岩、戈壁、流动沙漠、风蚀裸地, 以及高 等植物稀少的河流、湖泊、海洋等水域。

植被亚型。系高级主要分类单位植被型之下的 辅助分类单位。在同一个植被型内, 主要依据生境 特点或生态条件, 同时也参考群落外貌上的明显差 异进行划分。如落叶针叶林根据其所在的生境温度 划分为寒温性和温性落叶针叶林与暖性落叶针叶林 两个亚型; 常绿针叶林根据其所在的生境温度划分 寒温性常绿针叶林、温性常绿针叶林、暖性常绿针 叶林、热性常绿针叶林 4 个亚型; 根据水分与土壤特 征和地理分布特点, 多数草本植被的植被型可以进 一步划分出荒漠草原、典型草原、草甸草原、高寒 草原、典型草甸、高寒草甸、沼泽草甸、盐生草甸 等亚型。部分植被型下没有划分亚型。如落叶与常 绿针叶混交林、肉质刺灌从、稀树草丛、高山垫状 植被、高山稀疏植被、木本沼泽、草本与苔藓沼泽 等。具体的划分结果见附录 I。

群系组。中级主要分类单位之上的辅助分类单 位。在同一个植被型或亚型范围内, 建群种为同属 植物的植物群落, 和多个植物种经常形成共优势组 合的植物群落联合即为群系组。需要强调的是, 建 群种为同属植物的群落也可以属于不同植被型或植 被亚型下的几个群系组。如栎属(Quercus)植物为建 群种的植物群落有生活型和生态上完全不同的植被 型, 在落叶阔叶林植被型下有落叶柇林群系组, 在 硬叶常绿阔叶林植被亚型下有高山栋林群系组。松 属(Pinus)植物为建群种的植物群落也有生态上明显 不同的多个类型, 在寒温性常绿针叶林植被亚型下 有寒温性松林群系组, 在温性常绿针叶林植被亚型 下有温性松林群系组, 在暖性常绿针叶林植被亚型 下有暖性松林群系组, 在热性常绿针叶林植被亚型 下有热性松林群系组。部分植被型或植被亚型之下 没有群系组, 或者可以看作仅包含一个群系的群系 
组, 如水杉属(Metasequoia)仅有水杉(Metasequoia glyptostroboides)一个种, 故水杉林群系组下只有水 杉林群系。

群系。中级主要分类单位。建群种或主要共建 种相同的植物群落联合即为群系。

亚群系。中级主要分类单位之下的辅助分类单 位。建群种生态幅度较广的群系, 由于分布生境的 不同, 群落的其他优势种和种类组成也可能存在明 显的差异。这时, 可以根据群落生境的综合特征和 建群种之外其他优势植物生活型以及生态习性等进 一步划分亚群系。对于绝大部分群系来说, 不需要 再划分亚群系。

群丛组。主要低级分类单位之上的辅助分类单 位。凡是层片结构相似, 且优势层片和次优势层片 的优势种或共优种(或标志种)相同的植物群落联合 即为群丛组; 对于层次结构较简单的植被类型, 次 优势层或层片的优势植物生活型和生态习性相同的 植物群落联合即为群从组。

群丛。植被分类低级单位。凡是物种组成基本 相同, 且层片结构和各层片的优势种或共优种(或 标志种)相同, 群落结构和动态特征(包括相同的季 相变化规律和演替阶段等) 以及生境相对一致, 具 有相似生产力的植物群落联合即为群丛。作为植被 分类的最基本的单位, 群丛一般在研究一个非常具 体的地点的植被时才能比较好地去划分, 或者在比 较系统地收集一个群系的大量样方数据之后才可能 得出较为准确的分类结果。

\section{3 中国植被类型的命名原则}

植物群落的命名在全世界并不统一, 在国内有 关植被专著中也很不一样, 甚至在部分专著不同章 节或不同高级分类单位下的命名方法也不一致, 因 此常常会产生理解上的困难, 对于非本专业人员尤 其如此。本方案沿用《中国植物区系与植被地理》 确定的, 突出建群种和优势种地位, 尽量反映群落 结构主要层次(或层片)特点, 并在能表述清楚的情 况下尽量简化的命名原则(陈灵芝等, 2014)。此处针 对各分类等级单位简略介绍, 有关对应的英文命名 方法参见本专辑的另两篇文章(方精云等, 2020; 王 国宏等, 2020)。

高级单位的植被类型以群落生态外貌特征来 命名。
植被型名称主要以外貌来命名，如“常绿针叶 林”植被型、“落叶阔叶灌从”植被型、“半灌木与草 本荒漠”植被型、“高山冻原”植被型、“草本与苔藓 沼泽”植被型等。

植被亚型名称命名时通常在植被型名称前再冠 以区分和限定亚型的生态特征，如“寒温性常绿针 叶林”植被亚型、“温性落叶阔叶灌从”植被亚型、“从 生草类高寒草原”植被亚型、“温性灌木荒漠”植被亚 型等。遵循“名称尽量简明”的原则，部分植被亚型 的名称虽然不包含生态特征的词汇，但实际上具有 一定的生态内涵，如“硬叶常绿阔叶林”植被亚型， 特指起源与地中海式气候联系较为密切, 且比较耐 旱的一类叶片硬革质化的常绿阔叶林, 与喜暖湿生 境的典型常绿阔叶林等有明显区别，名称中的“硬 叶”虽然属于形态方面的词汇，但包涵着适应季节 干旱的生态信息。部分名称沿用了《中国植被》等 以往的一些习惯用法, 如“季风常绿阔叶林”。

中级单位的植被类型主要以群落建群种的种属 名称命名, 并加上描述植被特征的词语(通常为较 高级单位的名称或简称)和等级单位的名称。

群系组名称主要用建群种属的名称命名。由于 一个属内不同物种的生态习性差异比较大, 以它们 为建群种的群落很可能被划分在不同的植被型或植 被亚型内, 此时群系组名称还要冠以描述群落外貌 (主要为植被型组或植被型)或生态特征(主要为植被 亚型)的词语加以区别。例如, 松属植物为建群种的 群落划分在4个不同的群系组, 分属于“寒温性常绿 针叶林” “温性常绿针叶林” “暖性常绿针叶林” “热 性常绿针叶林” 等植被亚型之下, 这些群系组的名 称要冠以描述温度带的限定性描述词语, 即“寒温 性松林”群系组、“温性松林”群系组、“暖性松林”群 系组和“热性松林”群系组。

群系名称通常直接用建群种名称命名。为避免 生态幅度较宽泛的物种在不同植被类型中都是建群 种而产生混淆, 应附加限定性词语加以区分。由共 建种组成的植物群系, 共建种名称之间用加号“+”” 相连。

亚群系名称用建群种种名和反映其亚群系生态 特性的词语来命名, 如“琐琐砾漠”就是指发育在砾 石质地表的琐琐荒漠亚群系。

植被类型低级单位的名称力求能充分反映群落 的主要特征, 特别是主要物种优势度顺序和群落结 
构上的层次关系。

群丛组名称主要以建群种种名和次优势层或层 片生活型名称来命名, 建群种种名通常置第一位, 建群种和次优势层生活型的名称之间用连接号“-” 连接。优势层存在两个或多个优势种时, 种名之间 用加号“+”连接。

群丛的命名则要尽可能地列出各层(或层片)的 优势植物(建群层为建群种)的种名, 使群落的层片 结构得到充分反映。

\section{4 植被型特征}

\section{1 森林植被型组}

乔木层为群落的优势层, 盖度大于 $20 \%$ 的植物 群落, 包括高度一般大于 $5 \mathrm{~m}$, 主秆明显的竹类为 群落建群种的竹林, 以及由于生境特殊(石质化㾑 薄土壤、海岛、海滨、山顶等) 而生长相对低矮的乔 木矮林。主要包括以下植被型:

(1)落叶针叶林: 以落叶针叶树种为主的植物 群落。主要为落叶松属(Larix)植物为建群种的落叶 松林。

(2)落叶与常绿针叶混交林: 以落叶针叶树和 常绿针叶树为主的混交林。其中, 落叶针叶树和常 绿针叶树的重要值都小于 $75 \%$ 。主要由落叶松属、 云杉属(Picea) 和松属植物组成。

(3)常绿针叶林: 以常绿针叶树种为主的植物群 落。主要为松科、柏科和杉科等科的常绿植物为建 群种的森林。

(4)针叶与阔叶混交林(简称针阔混交林): 由针 叶树和阔叶树混合组成的植物群落。其中, 针叶乔 木和阔叶乔木重要值在乔木层重要值中占比都小于 $75 \%$ 。温带地区主要为松属植物与落叶阔叶树组成 的混交林; 亚热带山地主要为铁杉属(Tsuga)植物与 阔叶树组成的混交林, 阔叶树中既有落叶阔叶树, 也有常绿阔叶树。另外, 亚热带地区还有大面积松 属植物与阔叶树组成的次生性混交林。

(5)落叶阔叶林: 以落叶阔叶树为主的植物群 落。群落类型很多, 建群种主要有栋属、水青冈属 (Fagus)、华木属(Betula)、我耳枥属(Carpinus)、杨 属(Populus)、柳属(Salix)、榆属(Ulmus)、槭属(Acer)、 椴树属(Tilia)等落叶乔木。落叶阔叶林主要分布在 温带和暖温带地区以及亚热带山地。

(6) 常绿与落叶阔叶混交林: 由常绿阔叶乔木
和落叶阔叶乔木混合组成的植物群落。群落类型极 为丰富, 建群种大多是落叶阔叶林中的喜暖建群种 和常绿阔叶林中的较耐冷建群种, 主要分布在北亚 热带地区和亚热带山地, 但在南方石灰岩山地也有 大面积分布。

(7)常绿阔叶林: 分布在亚热带和北热带山地湿 润地区, 以常绿阔叶乔木为主组成的乔木层高度通 常在 $20 \mathrm{~m}$ 左右的植物群落。建群种主要为壳斗科、 樟科、山茶科、金缕梅科、木兰科、杜英科等的常 绿乔木。硬叶常绿阔叶林合并在该植被型中作为一 个植被亚型, 以体现其在生态上的独特性。

(8)雨林: 分布在湿润热带地区, 以常绿阔叶乔 木为主组成的乔木层通常高度在 $30 \mathrm{~m}$ 以上的植物 群落。中国大陆的热带地区地处热带北缘, 仅有季 节性雨林, 包括典型季节性雨林和山地季节性雨 林等。

(9)季雨林: 分布在热带季风气候影响下具有明 显干湿季节的区域，且上层乔木全部或大部分在旱 季末期落叶, 是介于季节性雨林和稀树草原之间的 类型。除了原生的季雨林之外，部分季雨林或季节性 雨林破坏后次生的植物群落也呈现季雨林特征。

(10)红树林：分布在热带和与之毗邻的亚热带 海滩, 特别是淤泥质海岸或河口湾高潮线以下的盐 沼土上, 以红树科、海桑科、大戟科等科的植物为 主组成的一种特殊的植被类型。红树林也被看作木 本沼泽的一种类型。

(11)竹林: 以高大乔木状竹类为群落建群种的 植物群落, 通常建群种优势度极大, 甚至常呈纯 林状。

\section{2 灌丛植被型组}

分布在降雨比较充足或地下水供应较充分的地 区, 以中生性的灌木和肉质具刺植物为主, 植株较 密集，群落灌木层覆盖度大于 $30 \%$ 的植被类型。

(12)常绿针叶灌丛: 以耐寒适低温的中生常绿 针叶灌木为建群种的植物群落。建群种主要为柏科 植物。常绿针叶灌从主要分布在高山和亚高山带, 温带山地和沙地等也有分布。

(13)落叶阔叶灌丛: 以冬季落叶的灌木种类为 建群种的植物群落。

(14)常绿阔叶灌丛: 热带和亚热带地区以常绿 阔叶灌木为主的植物群落。常绿阔叶灌从部分是原 生的, 尤其是在低纬度地区高山和亚高山带, 含以 
往单独作为一个植被型的常绿革叶灌从。低海拔地 区常绿润叶灌从大部分是森林破坏后次生的。

(15)肉质刺灌丛: 热带海滨沙地和热带、亚热带 干热河谷底部干热气候环境中分布的以仙人掌 (Opuntia spp.)、霸王鞭(Euphorbia royleana)等肉质 具刺灌丛占优势的次生性植物群落, 其中次优势种 和常见的伴生种仍主要是原耐旱疏林或灌从中的主 要成分。

(16)竹丛: 以高度通常不超过 $5 \mathrm{~m}$ 的丛生竹类 为主的植物群落。

\section{3 草本植被(草地)植被型组}

“草地” 是一个比较模糊的概念, 不同学科、不 同学者的理解存在巨大差异(中华人民共和国农业 部畜牧兽医司和全国畜牧兽医总站, 1996; 沈海花 等, 2016)。在本分类方案中, 草本植被(草地)定义为 主要由旱生和中生草本植物组成的植物群落, 包括 《中国植被》等植被生态学专著中的以草本植物为 主要组分的草原、草甸、灌草从和稀树草原等类型, 但不包含湿生环境中的草本沼泽、(高山)严寒环境 中的草本冻原、极端干旱环境中的半灌木与草本荒 漠等植被类型。

(17)丛生草类草地：以多年生丛生型地面芽草 本植物为主的植物群落。从生草类草地中也常有根 茎草和杂类草、半灌木, 有时还有少量灌木, 在沙地 等特殊生境还会有稀疏的乔木生长, 但这些灌木和 乔木层处于次要地位。

(18)根茎草类草地: 以多年生根茎地下芽草本 植物为主的植物群落。根茎草类草地中也常有丛生 草和杂类草、半灌木, 有时还有少量灌木, 在沙地等 特殊生境还会有稀疏的乔木生长, 但这些灌木和乔 木层处于次要地位。

(19)杂类草草地：以多年生杂类草为主的植物 群落。杂类草草地一般也含有少量禾草和半灌木。

(20)半灌木草地: 以枝条主要为草质, 仅基部 微弱木质化的半灌木为主, 并含有较多草本植物的 植物群落。

(21)灌草丛: 森林或灌丛等中生性植被在遭受 持续干扰条件下, 形成以中生多年生草本植物为主, 并含有少量灌木的次生性植物群落, 通常认为是植 物群落演替过程中的一个草本植物为主的阶段。因 为群落自然演替的方向是其原生的植被类型, 因此, 常有原来群落中残留的, 或者新入侵的灌木生长。
(22)稀树草丛: 在北热带和亚热带南部较干燥 的地区, 如海南西部和滇、桂、黔、川的干热河谷, 以 中生和旱中生草本植物为主, 含有稀疏乔木和灌木 的类似热带非洲稀树草原外貌特征的植物群落, 稀 树草原虽然也被认为是次生的, 但其环境较为干燥, 草本植物群落也较为稳定。

\section{4 荒漠植被型组}

温带和高寒地区降水量通常不足 $250 \mathrm{~mm}$ 的极 端干旱环境, 由超旱生植物为主组成的植物群落。 荒漠中的草本植物可以是耐旱和耐盐碱的, 但也可 以是旱生性甚至中生性的, 尤其是一年生短命草本 植物和多年生的类短命植物。另外, 群落在生长季 的大部分时段表现得比较稀疏, 但在某些时段, 比 如春季, 由短命植物和类短命植物组成的春季层片 的覆盖度可以很高, 甚至达到 $90 \%$ 以上。

(23)半乔木与灌木荒漠: 以超旱生半乔木和灌 木为主组成的稀疏植物群落。其中, 在准噶尔盆地 古尔班通古特沙漠中, 以半乔木琐琐 (Haloxylon ammodendron)和白琐琐 (H. persicum) 为建群种的植 物群落通常也称为半乔木荒漠, 但在其他生境中生 长的琐琐却常呈现为灌木状, 当属于灌木荒漠。

(24)半灌木与草本荒漠: 以超旱生半灌木和草 本植物为主组成的植物群落。

\section{5 高山冻原与稀疏植被植被型组}

分布在林线以上高山带, 由适寒冷植物组成的 植被类型, 包括高山冻原、高山垫状植被和高山稀 疏植被。

(25)高山冻原：分布在东北长白山和新疆阿尔 泰山高山带, 由贴地生长的矮小灌木、草本植物、 苔藓、地衣组成的较为密集的植被类型。

(26)高山垫状植被: 主要分布在青藏高原和西 北干旱区高山带, 由适寒冷的垫型小半灌木或垫状 多年生草本植物占优势的植物群落。垫状植被通常 成片状分布在高寒草原和高寒草甸以及高山稀疏植 被常分布的地方, 常占据山险垭口两侧、湖滨阶地、 冰水台地等地段。

(27)高山稀疏植被: 高山永久冰雪带之下的亚 冰雪带, 地表仍主要受物理风化而形成多石块的流 石坡, 土壤发育微弱, 只有少量耐寒的适冰雪植物 散生其间, 植物总覆盖度通常不足 $5 \%$ 。

\section{6 沼泽与水生植被(湿地)植被型组}

沼泽与水生植被是土地利用类型和生态系统概 
念中湿地的最主要的植被类型。其中, 沼泽是在土 壤水分饱和或适度积水的环境中由湿生植物组成的 植物群落。组成沼泽的湿生植物, 比较常见的是草 本植物和藓类, 也有以灌木甚至乔木为建群种的群 落类型。水生植被则指生长在水体中由水生植物组 成的植被。

(28)木本沼泽: 以耐湿木本植物为主组成的沼 泽。

(29)草本与苔蘚沼泽：以湿生多年生草本植物 和藓类植物为主组成的沼泽。

(30)水生植被: 生长在水体中, 由挺水、浮叶、 漂浮和沉水的水生植物组成的植物群落。

\section{7 农业植被植被型组}

以获取农产品为目标, 由人工栽培和持续管理 的植被类型。农业植被型组包括粮食作物、油料作 物、纤维作物、糖料作物、药用作物、饮料作物、 饲料作物、烟草作物、菜园、果园、花卉园、其他 经济作物共 12 个植被型, 即按农业植被用途或功能 型划分。

\section{8 城市植被植被型组}

以绿化、美化和环境保护为目标, 由人工栽培 或自然存留在城市环境中的植被类型。城市植被型 组包括城市森林、城市草地、城市湿地、城市行道 树及城市公园植被(复合类型)等 5 个植被型。

\section{9 无植被地段(含微型低等植物植被)}

完全缺少高等植被覆盖, 或以微型地衣、藻类 等低等植物为主, 偶然有极个别高等植物生长的地 段, 包括冰川、多年积雪、盐壳、裸山、熔岩、戈 壁、流动沙漠、风蚀裸地, 以及高等植物稀少的河 流、湖泊、海洋等水域。

\section{5 有关中国植被分类系统若干问题的讨论}

\section{1 中国植被分类系统总体框架}

修订中国植被分类系统首先涉及系统的总体框 架和结构, 以及如何与国际上主要的植被分类系统 相衔接, 方便学术交流和区域间的植被比较和分析。 过去几十年来, 特别是近年来已有较多的相关讨论 和有益建议(黄威廉等, 1988; 中国科学院中国植被 图编辑委员会, 2007b; 宋永昌, 2011, 2017; 陈灵芝 等, 2014)。本次中国植被分类系统修订, 仍采用《中 国植被》确立的 “植物群落学-生态学”为基础的植被 分类方法和总体框架, 主要基于以下几点考虑:
首先，中国是世界上植被类型最复杂的国家之 一, 但中国植被研究的深入程度总体上仍较欠缺, 可用于植被分类的植被样方数据不足，而且有限的 资料尚很难实现全面共享。加上植被地域性特点突 出, 受环境因素的影响复杂。因此, 很难套用国外已 有的任何一个植被分类系统及其分类指标。相对于 欧洲大陆学派以植物区系组成和特征种为核心的植 被分类方法, “植物群落学-生态学”为基础的植被分 类方法更适合中国植被的现实情况，其自上而下、 逐步细化的操作过程更适宜于环境条件差异巨大, 植被类型复杂多变, 人类活动影响历史久远, 可用 植被研究数据相对匮乏的情况。

其次, 尽管《中国植被》确定的以“植物群落学生态学” 为基础的中国植被分类方法和主要内容也 并非完美, 但已在地学、林学、生态学等相关学科 领域得到长期、广泛的应用, 并被大多数植被生态 学学者熟悉和接受。目前, 绝大部分关于中国植被 的研究专著和论文都应用了这一方法, 或在此框架 基础上进行了部分修订。

再次, 如同大部分学科的发展规律一样, 中国 植被生态学在过去的半个多世纪得到了迅猛的发展, 有关植被的多学科交叉研究也越来越明显。同时, 植被分类的方法和框架也展现出了明显的多样化和 个性化趋势(黄威廉等, 1988; 中国科学院青藏高原 综合科学考察队, 1988; 金振洲和欧晓昆, 2000; 宋 永昌, 2011, 2017; 陈灵芝等, 2014; 苏宗明等, 2014; 王献溥等, 2014; Guo et al., 2018; 朱华, 2018; 杨小 波, 2019)。在此背景下, 求同存异建立统一的植被分 类系统确有必要, 但完全消除观点分歧的难度很 大。因此, 本次修订具有广泛的包容性, 在能够反映 主要区别的基础上尽量不增加甚至简化分类阶层, 方便人们掌握植被分类的要点和实际应用。

最后, 新的分类方案是基于中国植被的特点和 植被生态学研究成果, 优先考虑有利于中国学者的 应用和研究, 同时兼顾与国际主要植被分类系统的 联系, 以期进一步完善中国植被分类系统。目前, 全 世界不同地区、不同学派有很多植被分类系统, 即 使联合国教科文组织的国际植被分类系统 (UNESCO, 1973)也没有被广泛接受和应用。为了方 便学术交流和植被分类学研究, 植被生态学界的主 流做法是通过比较来寻求分类系统间的对应性(De Cáceres et al., 2015, 2018), 由此建立起彼此的联系, 
目前还很难看到建立起全球统一植被分类系统的日 期。所以, 建立中国植被分类系统与国际上主要植 被分类系统之间的对应关系, 是实现与国际交流的 现实有效途径。

\section{2 混交林的概念与定量化处理方式}

混交林的概念以前没有严格定义, 所以使用较 为随意, 同一个植物群落地段就可能被定义为不同 的植物群落类型而划分到不同的植被型。本次修订 特别规定, 植被型层面的“混交林”指生活型的混交, 即针叶树与阔叶树个体之间的混交, 落叶树与常绿 树的混交。同为落叶阔叶树的两个或多个植物种, 或同为常绿阔叶树的两个或多个植物种, 或同为常 绿针叶树的两个或多个植物种成为共优势种的群落, 不再称为混交林。另外, 由一种生活型占绝对优势 而另一种生活型所占比例很小或仅有个别植株的 群落不宜称为混交林。为此规定, 混交林的两类生 活型植物的重要值都应介于 $25 \%-75 \%$ 之间(FaberLangendoen et al., 2014)。

\section{3 落叶与常绿针叶混交林}

落叶与常绿针叶混交林是在中国很多地方较常 见的一类混交林, 如分布在天山东端相对干旱生境 的西伯利亚落叶松+雪岭云杉落叶与常绿针叶混交 林、阿尔泰山的西伯利亚落叶松+西伯利亚云杉落 叶与常绿针叶混交林(王国宏, 2017), 华北山地广泛 分布的华北落叶松+白扞落叶与常绿针叶混交林(郭 东罡, 2014; 王国宏, 2017)。这些混交林以前没有单 独作为一个植被型, 而是将其合并为落叶针叶林植 被型或常绿针叶林植被型。随着近年来调查资料的 丰富, 这些森林群落类型的特征和分布已逐渐明晰, 其自然稳定性和原生性也是极为鲜明的, 可以考虑 单独作为落叶与常绿针叶混交林植被型列出。

\section{4 关于草本植被和草地、沼泽与水生植被和湿地 的概念}

草地、湿地等概念一般作为土地利用类型或生 态系统类型的术语, 在植被类型的描述中也使用, 但分类含义比较模糊, 特别是草地的概念有很多不 同的理解。《中国草地资源》绪论中明确提到“根据 全国农业区划委员会、农业部、林业部、国家土地 管理局等有关部门商定, 全国首次统一草地资源调 查所涉及的草地，包括：植被总覆盖度 $>5 \%$ 的各类 天然草地, 以牧为主的树木郁闭度 $<0.3$ 的疏林草地 和灌从郁闭度 $<0.4$ 的疏灌从草地.......”“还包括沼泽
地、苇地、沿海滩涂; 植被总覆盖度 $>5 \%$ 的高寒荒 漠、苔原、盐碱地、沙地、石砾地……” (中华人民 共和国农业部畜牧兽医司和全国畜牧兽医总站, 1996)。本次植被分类系统修订期间曾经有人建议， 将以往《中国植被》等植被专著中的草原、草甸两 个植被型组合并为草地植被型组, 将沼泽和水生植 被划为一个植被型组, 称为湿地。这种处理方式从 生态系统分类的高级单位考虑也有一定的合理性, 但植被型组名称用词上仍有不同意见。目前暂使用 “草本植被(草地)”植被型组, 沿用“沼泽与水生植 被”植被型组。

“草本植被(草地)”植被型组包含了以往的草 原、草甸、草丛和干热河谷稀树草原(稀树草丛)。 这种处理主要是考虑了草原和草甸都是以草本植物 (有时是植物体主体部分为草质的半灌木)为优势种 组成的植被类型, 种类组成和外貌都较为相似, 空 间上常常沿水分梯度连续分布或镶嵌分布。

\section{5 硬叶常绿阔叶林合并到常绿阔叶林}

本次植被分类系统修订将硬叶常绿阔叶林作为 常绿阔叶林植被型下的一个亚型处理, 而不再作为 独立的植被型与后者并列。这样处理主要是认定硬 叶常绿阔叶林应该属于常绿洞叶林, 但其与常绿阔 叶林中的其他植被亚型有明显的区别, 主要是分布 在相对干暖的生境, 特别是年内气候上有一个明显 的旱季, 温度适应范围也较广, 并可分布在亚热带 地区较为寒冷的亚高山带。另外, 硬叶常绿阔叶林 在常绿阔叶林分布区域的石质山坡或干旱山脊部分 也常见片断分布，反映其相对耐旱、耐贫㾑土壤的 特性。

\section{6 常绿革叶灌丛}

《中国植被》将常绿革叶灌从与常绿针叶灌从、 落叶阔叶灌从、常绿阔叶灌从等并列, 作为单独的 一个植被型, 并且定义其为“由耐寒的、中旱生的常 绿革叶灌木为建群层片, 苔藓植物为亚建群层片” 的植被类型(中国植被编辑委员会，1980)。实际上， 常绿革叶灌从特指分布在青藏高原周边山地上部和 亚高山带以杜鹃花科灌木为建群种的灌从。但客观 地说, 这些建群种应该主要分布于中生性生境。后 来, 常绿革叶灌从也逐渐包括了高山栋为建群种的 一些灌丛(陈灵芝等, 2014)。鉴于这些常绿革叶灌木 叶片的常绿阔叶性质以及很多其他常绿阔叶灌木的 叶片也具有厚革质的特点, 从形态学上难以区分, 
此次将这类分布在相对寒旱生境下的常绿革叶灌从 合并到常绿阔叶灌丛植被型下, 作为一个适应寒旱 生境的植被亚型。

\section{7 针叶、阔叶等叶片生活型和植被类型的划分仍 有待完善}

针叶与阔叶的叶片形态差异是群落外貌和植被 分类的重要划分依据, 但在具体操作过程中, 有时 还存在界定模糊的问题。目前的通用处理方式是, 针叶植物被限定在裸子植物中, 包括罗汉松 (Podocarpus macrophyllus) 类植物, 但裸子植物中的 银杏(Ginkgo biloba) 却是作为阔叶树来对待的; 被 子植物则一般作为阔叶植物对待，尽管其中有许多 植物的叶片为针形、线形或鳞片形, 如岩高兰 (Empetrum nigrum)的叶片为短线形, 柽柳(Tamarix spp.)、水柏枝(Myricaria spp.)、木麻黄(Casuarina spp.) 等叶片退化成鳞片状, 但在分类系统中仍将其 置于阔叶林或阔叶灌丛内(中国植被编辑委员会, 1980; 陈灵芝等, 2014)。未来需要对这些类型再做 出进一步限定, 比如对阔叶或针叶给出准确的定义, 并按照准确的生活型定义来划分这些植物为优势种 的植被属性。美国植被分类系统的生活型定义中就 将鳞形叶合并在针叶类型中, 但举例都是裸子植物, 未提到上述鳞形叶的属(Faber-Langendoen et al., 2014)。

\section{8 土壤特性对植被形成的重要性有待在植被分类 系统得到进一步体现}

侯学显(1994)在总结其一生植被生态学研究体 会时指出: “植被分类的目的, 就是要把所划分出来 的分类单位, 既能表示植物资源分布的情况, 又要 能反映该分类单位所在地的综合生态因素(气候和 土壤)的特点, 这样才有可能为利用自然、改造自然 和国土整治提供基本资料。”在阐述植被分类问题 和植被地带性问题时他进一步指出: “决定植被的生 存条件不仅是气候, 也决定于土壤, 只有气候和土 壤因素形成的综合生境, 才是影响植被类型形成的 全面外界因素。”他多次举例提到中国南方和西南 地区大面积石灰岩土壤上生长的与当地酸性土上不 同的植被类型。另外, 如荒漠地区依靠地表短暂洪 水和地下水生存的河岸落叶阔叶林与温带湿润地区 依靠自然降水的落叶阔叶林在种类组成、群落结构 和生态特征上都具有巨大的差别。目前的分类系统 中对气候地带性关注较多, 对土壤、岩石性质和地
下水特性等因素关注相对不足, 未来在进一步细化 植被分类系统时有必要加以强调。

\section{9 农业植被、城市植被、无植被地段}

栽培植被是根据人类的意愿而人为构建的植物 群落, 种类组成、群落结构、生态外貌和群落动态 等都受人类的控制。因而, 栽培植被的分类很难套 用自然植被的分类原则和依据。《中国植被》一书 曾对栽培植被单独制定了一套分类原则和分类系 统。本次修订中国植被分类系统时, 将农业植被和 城市植被分别作为两个特殊的植被型组对待, 但植 被型组下植被型的划分主要依据农业作物和城市植 被的功能类型, 如粮食作物、果园等和城市森林、 城市行道树等。群系类型的进一步划分则主要依据 优势植物种类组成。此外, 对于如裸露石山、裸露 戈壁和雪山等无高等植物生长的地段, 目前的系统 也认定其为一个植被型组, 暂定名为无植被地段或 低等植物生长地段。无植被地段目前还没有一个特 别准确的定义, 定性的理解是基本没有高等植物生 长的地段; 如果给一个定量的概念, 建议采用“随机 取样的 10 个样方(草本植物按照 $1 \mathrm{~m}^{2}$, 灌木按照 25 $\mathrm{m}^{2}$ ), 平均每个样方植株数量不足 1 株, 同时没有一 个样方盖度超过 $1 \%$ 的地段”。

致谢 感谢众多专家在讨论中国植被分类系统修订 方案中所提出的宝贵意见和建议。

\section{参考文献}

Brown LR, Bredenkamp GJ (2018). An overview of the vegetation classification approach in South Africa. Phytocoenologia, 48, 163-170.

Chen LZ, Sun H, Guo K (2014). Flora and Vegetation Geography of China. Science Press, Beijing. [陈灵芝, 孙航, 郭柯 (2014). 中国植物区系和植被地理. 科学出版社, 北京.]

Chien SS, Wu CY, Chen CT (1956). The vegetation types of China. Acta Geographica Sinica, 22, 37-92. [钱崇澍, 吴 征镒, 陈昌笃 (1956). 中国植被的类型. 地理学报, 22, 37-92.]

Chytrý M, Tichý L (2018). National vegetation classification of the Czech Republic: a summary of the approach. Phytocoenologia, 48, 121-131.

De Cáceres M, Chytrý M, Agrillo M, Attorre F, Botta-Dukát Z, Capelo J, Czúcz B, Dengler J, Ewald J, Faber-Langendoen D, Feoli E, Franklin SB, Gavilán R, Gillet F, Jansen F, et al. (2015). A comparative framework for broad-scale plot-based vegetation classification. Applied Vegetation Science, 18, 543-560. 
De Cáceres M, Franklin SB, Hunter JT, Landucci F, Dengler J, Roberts DW (2018). Global overview of plot-based vegetation classification approaches. Phytocoenologia, 48, 101-112.

Dengler J, Bergmeier E, Willner W, Chytrý M (2013). Towards a consistent classification of European grasslands. Applied Vegetation Science, 16, 518-520.

Department of Animal Husbandry and Veterinary of the Ministry of Agriculture of the People's Republic of China, Nation's General Station of Animal Husbandry and Veterinary of China (1996). Rangeland Resources of China. China Science and Technology Press, Beijing. [中华人民 共和国农业部畜牧兽医司, 全国畜牧兽医总站 (1996). 中国草地资源. 中国科学技术出版社, 北京.]

Editorial Board of Vegetation Map of China, Chinese Academy of Sciences (2001). 1:1 000000 Vegetation Atlas of China. Science Press, Beijing. [中国科学院中国植被图编辑委 员会 (2001). 1:1000 000中国植被图集. 科学出版社, 北京.]

Faber-Langendoen D, Keeler-Wolf T, Meidinger D, Tart D, Hoagland B, Josse C, Navarro G, Ponomarenko S, Saucier J-P, Weakley A, Comer P (2014). EcoVeg: a new approach to vegetation description and classification. Ecological Monographs, 84, 533-561.

Faber-Langendoen D, Baldwin K, Peet RK, Meidinger D, Muldavin E, Keeler-Wolf T, Josse C (2018). The EcoVeg approach in the Americas: U.S., Canadian and International Vegetation Classifications. Phytocoenologia, 48, 215-237.

Fang JY, Guo K, Wang GH, Tang ZY, Xie ZQ, Shen ZH, Wang RQ, Qiang S, Liang CZ, Da LJ, Yu D (2020). Vegetation classification system and classification of vegetation types used for the compilation of vegetation of China. Chinese Journal of Plant Ecology, 44, 96-110. [方 精云, 郭柯, 王国宏, 唐志尧, 谢宗强, 沈泽吴, 王仁 卿, 强胜, 梁存柱, 达良俊, 于丹 (2020). 《中国植被 志》的植被分类系统、植被类型划分及编排体系. 植物 生态学报, 44, 96-110.]

Gellie NJH, Hunter JT, Benson JS, Kirkpatrick JB, Cheal DC, McCreery K, Brocklehurst P (2018). Overview of plotbased vegetation classification approaches within Australia. Phytocoenologia, 48, 251-272.

Gillet F, Julve P (2018). The integrated synusial approach to vegetation classification and analysis. Phytocoenologia, $48,141-152$.

Guangdong Institute of Botany (1976). Vegetation of Guangdong. Science Press, Beijing. [广东省植物研究所 (1976). 广东植被. 科学出版社, 北京.]

Guarino R, Willner W, Pignatti S, Attorre F, Loidi JJ (2018). Spatio-temporal variations in the application of the BraunBlanquet approach in Europe. Phytocoenologia, 48, 239250.

Guo DG, Shangguan TL, Ma XY, Hao J, Bi RC (2014). Vegetation of Shanxi: Needleleaf Forest Volume. Science Press, Beijing. [ 郭东罡, 上官铁梁, 马晓勇, 郝婧, 毕润成
(2014). 山西植被志: 针叶林卷. 科学出版社, 北京.]

Guo K, Liu CC, Xie ZQ, Li FY, Franklin SB, Lu ZJ, Ma KP (2018). China Vegetation Classification: concept, approach and applications. Phytocoenologia, 48, 113-120.

Hou XY (1960). China's Vegetation. People's Education Press, Beijing. [侯学显 (1960). 中国的植被. 人民教育出版社, 北京.]

Hou XY (1994). The contribution of mine to plant ecology and the viewpoints on some ecological problems//Editorial Committee of Researches on Vegetation Ecology. Researches on Vegetation Ecology-A Commemoration for Famous Ecologist Professor Нои Хиеуи. Science Press, Beijing. 13-23. [侯学煜 (1994). 我的植物生态学工作 及对其相关问题的一些观点//植被生态学研究编辑委员 会. 植被生态学研究——纪念著名生态学家侯学暗教 授. 科学出版社, 北京. 13-23.]

Huang WL, Tu YL, Yang L (1988). Vegetation of Guizhou. Guizhou People's Publishing House, Guiyang. [黄威廉, 屠玉麟，杨龙 (1988). 贵州植被. 贵州人民出版社，贵 阳.]

Jin ZZ, Ou XK (2000). Yuanjiang, Nujiang, Jinshajiang, Lancangjiang Vegetation of Dry-Hot Valley. Yunnan University Press, Yunnan Science and Technology Press, Kunming. [金振洲，欧晓昆 (2000). 元江、怒江、金沙江、 澜沧江干热河谷植被. 云南大学出版社, 云南科技出版 社, 昆明.]

Lavrenko EM (1959). The Principals of Plant Communities and the Research Methods. Science Press, Beijing. [拉甫连科 (1959). 植物群落的基本规律及其研究途径. 科学出版 社, 北京.]

MacKenzie WH, Meidinger DV (2018). The Biogeoclimatic Ecosystem Classification Approach: an ecological framework for vegetation classification. Phytocoenologia, 48, 203-213.

Peet RK, Palmquist KA, Wentworth TR, Schafale MP, Weakley AS, Lee MT (2018). Carolina Vegetation Survey: an initiative to improve regional implementation of the U.S. National Vegetation Classification. Phytocoenologia, 48, 171-179.

Qian YQ (2004). Chinese Academic Dictionary of the 20th Century: Volume of Biology. Fujian Education Press, Fuzhou. 202-209. [钱迎倩 (2004). 20世纪中国学术大典: 生物 学. 福建教育出版社, 福州. 202-209.]

Rodwell JS (2018). The UK National Vegetation Classification. Phytocoenologia, 48, 133-140.

Shen HH, Zhu YK, Zhao X, Geng XQ, Gao SQ, Fang JY (2016). Analysis of current grassland resources in China. Chinese Science Bulletin, 61, 139-154. [沈海花, 朱言坤, 赵霞, 耿晓庆, 高树琴, 方精云 (2016). 中国草地资源 的现状分析. 科学通报, 61, 139-154.]

Song YC, Yan ER, Song K (2017). An update of the vegetation classification in China. Chinese Journal of Plant Ecology, 41, 269-278. [宋永昌, 阎恩荣, 宋坤 (2017). 再议中国 的植被分类系统. 植物生态学报, 41, 269-278.] 
Song YC (2011). Recognition and proposal on the vegetation classification system of China. Chinese Journal of Plant Ecology, 35, 882-892. [宋永昌 (2011). 对中国植被分类 系统的认知和建议. 植物生态学报, 35, 882-892.]

Song YC (2017). Vegetation Ecology. 2nd ed. Higher Education Press, Beijing. [宋永昌(2017). 植被生态学. 2版. 高 等教育出版社, 北京.]

Su ZM, Li XK, Ding T, Ning SJ, Chen WL, Mo XL (2014). The Vegetation of Guangxi: Vol. 1. China Forestry Publishing House, Beijing. [苏宗明, 李先琨, 丁涛, 宁世江, 陈伟烈, 莫新礼 (2014). 广西植被: 第一卷. 中国林业 出版社, 北京.]

The Editorial Committee of Vegetation Map of China, Chinese Academy of Sciences (2007a). Vegetation Map of the People's Republic of China 1:1 000 000. Geological Publishing House, Beijing. [中国科学院中国植被图编辑委 员会 (2007a). 中华人民共和国植被图1:1000 000. 地 质出版社，北京.]

The Editorial Committee of Vegetation Map of China, the Chinese Academy of Sciences (2007b). Vegetation of China and Its Geographic Pattern-Illustration of the Vegetation Map of the People's Republic of China (1:1000 000). Geological Publishing House, Beijing. [中国科学院中国 植被图编辑委员会 (2007b). 中国植被及其地理格局 一一华人民共和国植被图(1:1000 000)说明书. 地质 出版社, 北京.]

The Editorial Committee of Vegetation of China (1980). Vegetation of China. Science Press, Beijing. [中国植被编辑委 员会 (1980). 中国植被. 科学出版社, 北京.]

The Scientific Expedition to the Qinghai-Xizang Plateau of the Chinese Academy of Sciences (1988). Vegetation of Xizang (Tibet). Science Press, Beijing. [中国科学院青藏高 原综合科学考察队 (1988). 西藏植被. 科学出版社, 北京.]

UNESCO (United Nations Educational, Scientific and Cultural Organization) (1973). International Classification and Mapping of Vegetation. UNESCO, Paris.

Walker DA, Daniëls FJA, Matveyeva NV, Šibík J, Walker MD, Breen AL, Druckenmiller LA, Raynolds MK, Bültmann
H, Hennekens S, Buchhorn M, Epstein HE, Ermokhina K, Fosaa AM, Heidmarsson S, et al. (2018). Circumpolar Arctic Vegetation Classification. Phytocoenologia, 48, 181-201.

Wang BS (1987). Approach to the horizontal zonation of monsoon forests. Acta Phytoecologica Geobotanica Sinica, 11, 154-158. [王伯蒜 (1987). 论季雨林的水平地带性. 植 物生态学与地植物学学报, 11, 154-158.]

Wang GH (2017). Spruce Forest of China. Science Press, Beijing. [王国宏 (2017). 中国云杉林. 科学出版社, 北京.]

Wang GH, Fang JY, Guo K, Xie ZQ, Tang ZY, Shen ZH, Wang RQ, Wang XP, Wang DL, Qiang S, Yu D, Peng SL, Da LJ, Liu Q, Liang CZ (2020). Contents and protocols for the classification and description of Vegetation Formations, Alliances and Associations of vegetation of China. Chinese Journal of Plant Ecology, 44, 128-178. [王国宏, 方精云, 郭柯, 谢宗强, 唐志尧, 沈泽吴, 王仁卿, 王裏 平, 王德利, 强胜, 于丹, 彭少麟, 达良俊, 刘庆, 梁存 柱 (2020). 《中国植被志》研编的内容与规范. 植物生 态学报, 44, 128-178.]

Wang XP, Guo K, Wen YG (2014). Records of Vegetation of Guangxi. Higher Education Press, Beijing. [王献溥, 郭柯, 温远光 (2014). 广西植被志要. 高等教育出版社, 北 京.]

Wiser SK, De Cáceres M (2018). New Zealand's plot-based classification of vegetation. Phytocoenologia, 48, 153-161.

Yang XB (2019). Vegetation of Hainan: Vol. 1. Science Press, Beijing. [杨小波 (2019). 海南植被志: 第一卷. 科学出 版社, 北京.]

Zhu H (2005). Reclassification of monsoon tropical forests in southern Yunnan, SW China. Acata Phytoecologica Sinica, 29，170-174. [朱华 (2005). 滇南热带季雨林的一些问 题讨论. 植物生态学报, 29, 170-174.]

Zhu H (2018). A sketch for classification of tropical forest vegetation in Yunnan. Guihaia, 38, 984-1004. [朱华 (2018). 云南热带森林植被分类纲要. 广西植物，38, 984-1004.]

责任编辑：谢 巍 
附录I 中国植被分类系统高级分类单位划分方案

Supplement I Classification scheme of upper level units of China Vegetation Classification System

\begin{tabular}{lll}
\hline $\begin{array}{l}\text { 植被型组 } \\
\text { Vegetation Formation } \\
\text { Group }\end{array}$ & $\begin{array}{l}\text { 植被型 } \\
\text { Vegetation Formation }\end{array}$ & $\begin{array}{l}\text { 植被亚型 } \\
\text { Vegetation Subformation }\end{array}$ \\
\hline 森林 Forest & 1. 落叶针叶林 Deciduous Needleleaf Forest & $\begin{array}{l}\text { 寒温性与温性落叶针叶林 } \\
\text { Cold-Temperate and Temperate Deciduous Needleleaf Forest } \\
\end{array}$ \\
& 暖性落叶针叶林 Subtropical Deciduous Needleleaf Forest
\end{tabular}

2. 落叶与常绿针叶混交林

Mixed Deciduous and Evergreen

Needleleaf Forest

3. 常绿针叶林 Evergreen Needleleaf Forest

寒温性常绿针叶林 Cold-Temperate Evergreen Needleleaf Forest

温性常绿针叶林 Temperate Evergreen Needleleaf Forest

暖性常绿针叶林 Subtropical Evergreen Needleleaf Forest

热性常绿针叶林 Tropical Evergreen Needleleaf Forest

4. 针叶与阔叶混交林

Mixed Needleleaf and Broadleaf Forest

温性针叶与落叶阔叶混交林

Temperate Mixed Needleleaf and Deciduous Broadleaf Forest

暖性针叶与阔叶混交林 Subtropical Mixed Needleleaf and Broadleaf Forest

亚热带山地针叶与阔叶混交林

Subtropical Montane Mixed Needleleaf and Broadleaf Forest

5. 落叶阔叶林 Deciduous Broadleaf Forest

寒温性落叶阔叶林 Cold-Temperate Deciduous Broadleaf Forest

温性落叶阔叶林 Temperate Deciduous Broadleaf Forest

暖性落叶阔叶林 Subtropical Deciduous Broadleaf Forest

6. 常绿与落叶阔叶混交林

Mixed Evergreen and Deciduous

Broadleaf Fores

北亚热带常绿与落叶阔叶混交林

Northern Subtropical Mixed Evergreen and Deciduous Broadleaf Forest

亚热带山地常绿与落叶阔叶混交林

Subtropical Montane Mixed Evergreen and Deciduous Broadleaf Forest

亚热带石灰岩山地常绿与落叶阔叶混交林

Subtropical Limestone Montane Mixed Evergreen and Deciduous Broadleaf Forest

7. 常绿阔叶林 Evergreen Broadleaf Forest

典型常绿阔叶林 Typical Evergreen Broadleaf Forest

季风常绿阔叶林 Monsoon Evergreen Broadleaf Forest

山地常绿阔叶林 Montane Evergreen Broadleaf Forest

硬叶常绿阔叶林 Sclerophyllous Evergreen Broadleaf Forest

山顶常绿阔叶矮林 Montane Ridge Evergreen Broadleaf Dwarf Forest

滨海常绿阔叶矮林 Coast Dwarf Forest

8. 雨林 Rainforest

雨林 Rainforest

山地雨林 Montane Rainforest

9. 季雨林 Monsoon Forest

10. 红树林 Mangrove Forest

11. 竹林 Bamboo Forest

灌从 Shrubland

\author{
12. 常绿针叶灌丛 \\ Evergreen Needleleaf Shrubland \\ 13. 落叶阔叶灌从 \\ Deciduous Broadleaf Shrubland
}
14. 常绿阔叶灌从 Evergreen Broadleaf Shrubland

15. 肉质刺灌从 Succulent Thorny Shrubland

16. 竹丛 Bamboo Shrubland
暖性竹林 Subtropical Bamboo Forest

热性竹林 Tropical Bamboo Forest

寒温性常绿针叶灌丛 Cold-Temperate Evergreen Needleleaf Shrubland

温性常绿针叶灌丛 Temperate Evergreen Needleleaf Shrubland

高寒落叶阔叶灌丛 Alpine Deciduous Broadleaf Shrubland

温性落叶阔叶灌丛 Temperate Deciduous Broadleaf Shrubland

暖性落叶阔叶灌丛 Subtropical Deciduous Broadleaf Shrubland

热性落叶阔叶灌从 Tropical Deciduous Broadleaf Shrubland

寒温性常绿阔叶灌丛 Cold-Tmperate Evergreen Broadleaf Shrubland

暖性常绿阔叶灌丛 Subtropical Evergreen Broadleaf Shrubland

热性常绿阔叶灌丛 Tropical Evergreen Broadleaf Shrubland

温性竹丛 Temperate Bamboo Shrubland

暖性竹丛 Subtropical Bamboo Shrubland 
附录I (续) Supplement I (continued)

\begin{tabular}{|c|c|c|}
\hline $\begin{array}{l}\text { 植被型组 } \\
\text { Vegetation Formation } \\
\text { Group }\end{array}$ & $\begin{array}{l}\text { 植被型 } \\
\text { Vegetation Formation }\end{array}$ & $\begin{array}{l}\text { 植被亚型 } \\
\text { Vegetation Subformation }\end{array}$ \\
\hline \multirow{31}{*}{$\begin{array}{l}\text { 草本植被(草地) } \\
\text { Herbaceous Vegetation } \\
\text { (Grassland) }\end{array}$} & \multirow[t]{8}{*}{ 17. 丛生草类草地 Tussock Grassland } & 丛生草类荒漠草原 Tussock Desert Steppe Grassland \\
\hline & & 丛生草类典型草原 Tussock Typical Steppe Grassland \\
\hline & & 丛生草类草甸草原 Tussock Meadow Steppe Grassland \\
\hline & & 丛生草类高寒草原 Tussock Alpine Steppe Grassland \\
\hline & & 丛生草类典型草甸 Tussock Typical Meadow Grassland \\
\hline & & 丛生草类高寒草甸 Tussock Alpine Meadow Grassland \\
\hline & & 丛生草类沼泽草甸 Tussock Swamp Meadow Grassland \\
\hline & & 丛生草类盐生草甸 Tussock Halophytic Meadow Grassland \\
\hline & \multirow[t]{7}{*}{ 18. 根茎草类草地 Rhizome Grassland } & 根茎草类典型草原 Rhizome Typical Steppe Grassland \\
\hline & & 根茎草类草甸草原 Rhizome Meadow Steppe Grassland \\
\hline & & 根茎草类高寒草原 Rhizome Alpine Steppe Grassland \\
\hline & & 根茎草类典型草甸 Rhizome Typical Meadow Grassland \\
\hline & & 根茎草类高寒草甸 Rhizome Alpine Steppe Grassland \\
\hline & & 根茎草类沼泽草甸 Rhizome Swamp Meadow Grassland \\
\hline & & 根茎草类盐生草甸 Rhizome Halophytic Meadow Grassland \\
\hline & \multirow[t]{8}{*}{ 19. 杂类草草地 Forb Grassland } & 杂类草荒漠草原 Forb Desert Steppe Grassland \\
\hline & & 杂类草典型草原 Forb Typical Steppe Grassland \\
\hline & & 杂类草草甸草原 Forb Meadow Steppe Grassland \\
\hline & & 杂类草高寒草原 Forb Alpine Steppe Grassland \\
\hline & & 杂类草典型草甸 Forb Typical Meadow Grassland \\
\hline & & 杂类草高寒草甸 Forb Alpine Meadow Grassland \\
\hline & & 杂类草沼泽草甸 Forb Swamp Meadow Grassland \\
\hline & & 杂类草盐生草甸 Forb Halophytic Meadow Grassland \\
\hline & \multirow[t]{4}{*}{ 20. 半灌木草地 Semi-Shrubby Grassland } & 半灌木荒漠草原 Semi-Shrubby Desert Steppe Grassland \\
\hline & & 半灌木典型草原 Semi-Shrubby Typical Steppe Grassland \\
\hline & & 半灌木草甸草原 Semi-Shrubby Meadow Steppe Grassland \\
\hline & & 半灌木高寒草原 Semi-Shrubby Alpine Steppe Grassland \\
\hline & \multirow[t]{2}{*}{ 21. 灌草丛 Shrubby Grassland } & 温性灌草丛 Temperate Shrubby Grassland \\
\hline & & 亚热带与热带灌草丛 Subtropical and Tropical Shrubby Grassland \\
\hline & \multirow[t]{2}{*}{ 22. 稀树草丛 Savanna-like Grassland } & 热带滨海沙地稀树草丛 Tropical Coast Sandland Savanna-like Grassland \\
\hline & & 干热河谷稀树草丛 Dry and Hot Valley Savanna-like Grassland \\
\hline \multirow[t]{4}{*}{ 荒漠 Desert } & \multirow{2}{*}{$\begin{array}{l}\text { 23. 半乔木与灌木荒漠 } \\
\text { Semi-Arbor and Shrub Desert }\end{array}$} & 温性半乔木荒漠 Temperate Semi-Arbor Desert \\
\hline & & 温性灌木荒漠 Temperate Shrub Desert \\
\hline & \multirow{2}{*}{$\begin{array}{l}\text { 24. 半灌木与草本荒漠 } \\
\text { Semi-Shrub and Herb Desert }\end{array}$} & 温性半灌木与草本荒漠 Temperate Semi-Shrub and Herb Desert \\
\hline & & 高寒矮半灌木荒漠 Alpine Dwarf Semi-Shrub Desert \\
\hline \multirow{6}{*}{$\begin{array}{l}\text { 高山冻原与稀疏植被 } \\
\text { Alpine Tundra and Sparse } \\
\text { Vegetation }\end{array}$} & \multirow[t]{4}{*}{ 25. 高山冻原 Alpine Tundra } & 矮灌木高山冻原 Alpine Dwarf Shrub Tundra \\
\hline & & 草类高山冻原 Alpine Herb Tundra \\
\hline & & 苔蘚高山冻原 Alpine Moss Tundra \\
\hline & & 地衣高山冻原 Alpine Lichen Tundra \\
\hline & \multirow{2}{*}{\multicolumn{2}{|c|}{$\begin{array}{l}\text { 26. 高山垫状植被 Alpine Cushion Vegetation } \\
\text { 27. 高山稀疏植被 Alpine Sparse Vegetation }\end{array}$}} \\
\hline & & \\
\hline \multirow{3}{*}{$\begin{array}{l}\text { 沼泽与水生植被 } \\
\text { Swamp and Aquatic } \\
\text { Vegetation }\end{array}$} & \multicolumn{2}{|l|}{ 28. 木本沼泽 Woody Swamp } \\
\hline & \multirow{2}{*}{$\begin{array}{l}\text { 29. 草本与苔蘚沼泽 } \\
\text { Herb and Moss Swamp }\end{array}$} & 草本沼泽 Herb Swamp \\
\hline & & 苔藓沼泽 Moss Swamp \\
\hline
\end{tabular}


附录I (续) Supplement I (continued)

\begin{tabular}{|c|c|c|}
\hline $\begin{array}{l}\text { 植被型组 } \\
\text { Vegetation Formation } \\
\text { Group }\end{array}$ & $\begin{array}{l}\text { 植被型 } \\
\text { Vegetation Formation }\end{array}$ & $\begin{array}{l}\text { 植被亚型 } \\
\text { Vegetation Subformation }\end{array}$ \\
\hline & 30. 水生植被 Aquatic Vegetation & $\begin{array}{l}\text { 挺水植被 Emerged Aquatic Vegetation } \\
\text { 浮叶植被 Rooted Floating Leaf Aquatic Vegetation } \\
\text { 漂浮植被 Floating Aquatic Vegetation } \\
\text { 沉水植被 Submerged Aquatic Vegetation }\end{array}$ \\
\hline $\begin{array}{l}\text { 农业植被 } \\
\text { Agricultural Vegetation }\end{array}$ & $\begin{array}{l}\text { 31. 粮食作物 Food Crop } \\
\text { 32. 油料作物 Oil Crop } \\
\text { 33. 纤维作物 Fiber Crop } \\
\text { 34. 糖料作物 Sugar Crop } \\
\text { 35. 药用作物 Medicinal Crop } \\
\text { 36. 饮料作物 Beverage Crop } \\
\text { 37. 饲料作物 Forage Crop } \\
\text { 38. 烟草作物 Tobacco Crop } \\
\text { 39. 菜园 Vegetable Farm } \\
\text { 40. 果园 Orchard } \\
\text { 41. 花卉园 Flower Garden } \\
\text { 42. 其他经济作物 Other Cash Crops }\end{array}$ & \\
\hline $\begin{array}{l}\text { 城市植被 } \\
\text { Urban Vegetation }\end{array}$ & $\begin{array}{l}\text { 43. 城市森林 Urban Forest } \\
\text { 44. 城市草地 Urban Grassland } \\
\text { 45. 城市湿地 Urban Wetland } \\
\text { 46. 城市行道树 Urban Street Tree } \\
\text { 47. 城市公园植被 Urban Park Vegetation }\end{array}$ & \\
\hline $\begin{array}{l}\text { 无植被地段 } \\
\text { Non-Vegetated Area }\end{array}$ & 48. 无植被地段 Non-Vegetated Area & \\
\hline
\end{tabular}

